\title{
Tutorial in oral antithrombotic therapy: Biology and dental implications
}

\author{
Hamid-Reza Fakhri ${ }^{1}$, Sok-Ja Janket ${ }^{2}$, Elizabeth-A. Jackson ${ }^{3}$, Alison-E. Baird ${ }^{4}$, Richard Dinnocenzo ${ }^{5}$, \\ Jukka-H. Meurman ${ }^{6}$ \\ ${ }^{1}$ DDS, Research Associate, General Dentistry, Boston University, Henry M. Goldman School of Dental Medicine, U.S.A \\ ${ }^{2}$ DMD, MPH, Research Associate professor, General Dentistry, Boston University, Henry M. Goldman School of Dental Me- \\ dicine, U.S.A \\ ${ }^{3} \mathrm{MD}, \mathrm{MPH}$, Assistant professor, Preventive Cardiology, Internal Medicine, University of Michigan, Ann Arbor, Michigan, U.S.A \\ ${ }^{4}$ MD, MPH, Professor, Neurological disorders and Stroke, SUNY Downstate Medical Center, Brooklyn, NY, USA \\ ${ }^{5}$ DMD,MD, Clinical Associate Professor, Oral and Maxillofacial surgery, Boston University, Henry M. Goldman School of \\ Dental Medicine, Boston, MA, U.S.A \\ ${ }^{6}$ DDS, MD, Professor, Department of Oral and Maxillofacial Diseases, Helsinki University Central Hospital, and Institute of \\ Dentistry, University of Helsinki, Helsinki, Finland
}

Correspondence:

Boston University School of Dental Medicine

100 East Newton Street, Rm. G-107C

Boston, MA 02118

skjanket@bu.edu

Fakhri HR, Janket SJ, Jackson EA, Baird AE, Dinnocenzo R, Meurman $\mathrm{JH}$. Tutorial in oral antithrombotic therapy: Biology and dental implications. Med Oral Patol Oral Cir Bucal. 2013 May 1;18 (3):e461-72. http://www.medicinaoral.com/medoralfree01/v18i3/medoralv18i3p461.pdf

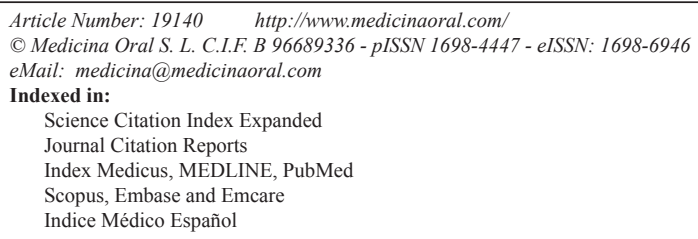

\begin{abstract}
Objectives: Recent developments of new direct oral anticoagulants that target specific clotting factors necessitate understanding of coagulation biology. The objective of this tutorial is to offer dental professionals a review of coagulation mechanisms and the pharmacodynamics of the conventional and new oral anticoagulants. Also, we summarized the dental implications of the conventional and new anticoagulants.

Method: We searched Medline using search terms "antithrombotic", "antihemostasis" or "anticoagulation" and combined them with the search results of "dental", "oral surgery" or "periodontal". We restricted the results to "human" and "English".

Results: The early coagulation cascade, the new cell-based coagulation model, the pharmacokinetics and pharmacodynamics of conventional antithrombotics, and new oral anticoagulants were reviewed. The new direct factor Xa inhibitors and the direct thrombin inhibitor (s), called direct oral anticoagulants (DOAs) have rapid onset of action, fast elimination on cessation, and fewer drug-drug or drug-food interactions than warfarin. However, the lack of antidotes raises concerns that some dental procedures may trigger serious hemorrhagic events. Additionally, careful perioperative withdrawal and resumption protocols for the DOAs are reviewed, because DOAs' blood levels are dependent on renal function. Also, various reversal strategies in the event of excessive bleedings are summarized. Perioperative management of dental patients taking new DOAs and conventional oral anticoagulants are also discussed. However, the perioperative strategies for DOAs are yet to be validated in randomized trials.
\end{abstract}

Key Words: Coagulation cascade, cell-based coagulation model, factor Xa inhibitors, direct thrombin inhibitors, prothrombin complex concentrates. 


\section{Introduction}

The increasing elderly population and long life-expectancy lead to a high prevalence of chronic illnesses including heart disease and stroke. (1) These diseases often require antithrombotic therapy to prevent thromboembolic (TE) events. The indications for antithrombotic therapy are to prevent TE events and stroke in: (I) Atrial fibrillation and other cardiac arrhythmias; (II) Venous thromboembolism (deep vein thrombosis, pulmonary embolism); (III) Acute coronary syndrome and myocardial infarction; (IV) Pulmonary hypertension; and (V) Cardiac valve disease and prosthetic valve replacement. $(2,3)$

Oral antithrombotic drugs can be divided into two categories: anti-platelets and anticoagulants. Table 1 sum- marizes these categories. Acetylsalicylic acid (aspirin) is the most widely used antiplatelet agent and the most commonly prescribed oral anticoagulant has been warfarin. Consequently, instructional articles automatically refer to oral anticoagulants as warfarin and its derivatives. $(2,4-7)$ However, the coagulation concept has been modified into a new, cell-based hemostasis model and several new oral anticoagulants targeting specific clotting factors have been introduced in $2010-2011$. Only recently, two cursory reviews on these new direct oral anticoagulants (DOAs) have appeared in the dental literature $(8,9)$. The objectives of the present review are (1) to educate general dental professionals about coagulation cascade and the pharmacology of new and old anticoagulants and (2) to suggest peri-surgical manage-

Table 1. Antithrombotic drugs categorized by pharmacodynamics.

\begin{tabular}{|c|c|c|}
\hline $\begin{array}{l}\text { Antithrombotic drug } \\
\text { categories }\end{array}$ & Generic names and subgroups & Comments \\
\hline Antiplatelet agents & $\begin{array}{l}\text { - COX-1 inhibitor: Aspirin } \\
\text { - ADP receptor inhibitor: } \\
\text { Clopidogrel, Prasugrel, Ticagrelor } \\
\text { - Gp IIb/IIIa inhibitor: } \\
\text { Abciximab, Eptifibatide, } \\
\text { Triofiban } \\
\text { - Phosphodiesterase inhibitor : } \\
\text { Dipyridamole } \rightarrow \text { Not licensed as a } \\
\text { monotherapy for stroke } \\
\text { prevention. }\end{array}$ & $\begin{array}{l}\text { - Bleeding time is extended without } \\
\text { clinical consequences. } \\
\text { - Gp IIb/IIIa inhibitor: Intra-venous use } \\
\text { only. } \\
\text { - Co-administration with NSAIDs increase } \\
\text { bleeding. } \\
\text { - Possible rebound effects on cessation. } \\
\text { - Dipyridamole is used in combination of } \\
\text { aspirin, } \\
\text { - Dipyridamole is indicated only when } \\
\text { other antiplatelets are not suitable. }\end{array}$ \\
\hline $\begin{array}{l}\text { Vitamin } \mathrm{K} \text { antagonists (VKA) } \\
\text { (inhibit factors II, VII, IX, X) }\end{array}$ & $\begin{array}{l}\text { Warfarin, Coumarin, Dicoumarol, } \\
\text { Phenprocoumon, Acenocoumarol. }\end{array}$ & $\begin{array}{l}\text { - VKA may be continued with local } \\
\text { hemostasis measures. } \\
\text { - VKA may be withdrawn for 2-3 days pre- } \\
\text { op. } \\
\text { - Consult with the prescriber of VKA. } \\
\text { - Interactions with many drugs and foods } \\
\text { - Possible rebound effects on cessation }\end{array}$ \\
\hline Factor Xa inhibitors & $\begin{array}{l}\text { - Heparin group: not reviewed } \\
\text { (subcutaneous use only) } \\
\text { - rivaroxaban }\end{array}$ & $\begin{array}{l}\text { - Heparin induced thrombocytopenia. } \\
\text { - No antidote for rivaroxaban }\end{array}$ \\
\hline Direct thrombin inhibitor & - dabigatran & $\begin{array}{l}\text { - No antidote. } \\
\text { Contraindications: } \\
\text { - Age }>75 \\
\text { - Renal dysfunction } \\
\text { - Bleeding tendency } \\
\sim 260 \text { hemorrhagic deaths in } 3 \text { years per } \\
\text { post-marketing surveillance by the } \\
\text { manufacturer, Boehringer Ingelheim. }\end{array}$ \\
\hline Thrombolytic drugs & $\begin{array}{l}\text { - tissue plasminogen activator } \\
\text { (tPA) } \\
\text { 1. Alteplase (tPA) } \\
\text { 2. Tenecteplase( tPA) } \\
\text { 3. Reteplase (tPA) } \\
\text { - Streptokinase (Kabikinase, } \\
\text { Streptase) } \\
\text { - Urokinase (Abbokinase) }\end{array}$ & $\begin{array}{l}\text { These agents will NOT be discussed in the } \\
\text { present review. } \\
\text { - Short term use } \\
\text { - Via Parenteral route }\end{array}$ \\
\hline
\end{tabular}

Reference for Table 1:

1 De Schryver, E. L., Algra, A. \& van Gijn, J. (2007) Dipyridamole for preventing stroke and other vascular events in patients with vascular disease. Cochrane Database Syst Rev, CD001820. doi:10.1002/14651858.CD001820.pub3 [doi]. 
ment strategies for patients taking new DOAs. Concurrently, we call for more research action utilizing these new DOAs in dental setting.

To conduct this review, we searched PubMed with search terms "anti-platelet", "antithrombotic", "anticoagulation", or "anti-hemostasis", published between 19662012 and in a separate search, we used the search terms "dental" "oral surgery" or "periodontal" and merged two searches. We collected 113 dentistry-related references. In the first section of this review, we reviewed the early coagulation cascade; in the second section, we introduced the new coagulation model; in the third section, we presented the new direct oral anticoagulants; and in the fourth section, we discussed perioperative management strategy.

\section{Concepts on early coagulation cascade}

Hemostasis involves a multipart physiological process that limits blood loss at the site of an injury while maintaining normal blood flow elsewhere in the circulation. An early model of coagulation derived from in vitro experiments and presented in the mid-1960s $(10,11)$ involved a series of biological steps via intrinsic and extrinsic pathways leading to a common pathway to activate factor X (f.X). The intrinsic pathway includes factors XII (f.XII), XI (f.XI), IX (f. IX) and VIII (f.VIII) as well as prekallikrein and kininogen. The extrinsic pathway is composed of factor VII (f.VII) and tissue factor (TF).

In the intrinsic pathway, activated f.XII leads to activated f. IX (f. IXa) after several steps of molecular activation. In turn, f. IXa converts f.X to activated f.X (f.Xa). On a collateral, extrinsic pathway, f.X can be activated by f.VII and tissue factor (TF/f.VII complex). Thus, f.Xa from both pathways converges in a common pathway whose constituents are factors $\mathrm{V}$ (f.V), prothrombin (f.II), fibrinogen (f.I) and thrombin.

Either way, activated f.X (f.Xa) is the key player in converting prothrombin (f.II) to thrombin, which converts fibrinogen (f.I) to fibrin. The activated partial thromboplastin time (aPTT) is a laboratory test for intrinsic pathway function and prothrombin time (PT) test assesses the function of the extrinsic pathway. (12) Each clotting factor leads to the activation of another, leading to a sufficient thrombin generation necessary for the formation of fibrin. This sequence of events is summarized in figure 1. Within this cascade model, the involvement

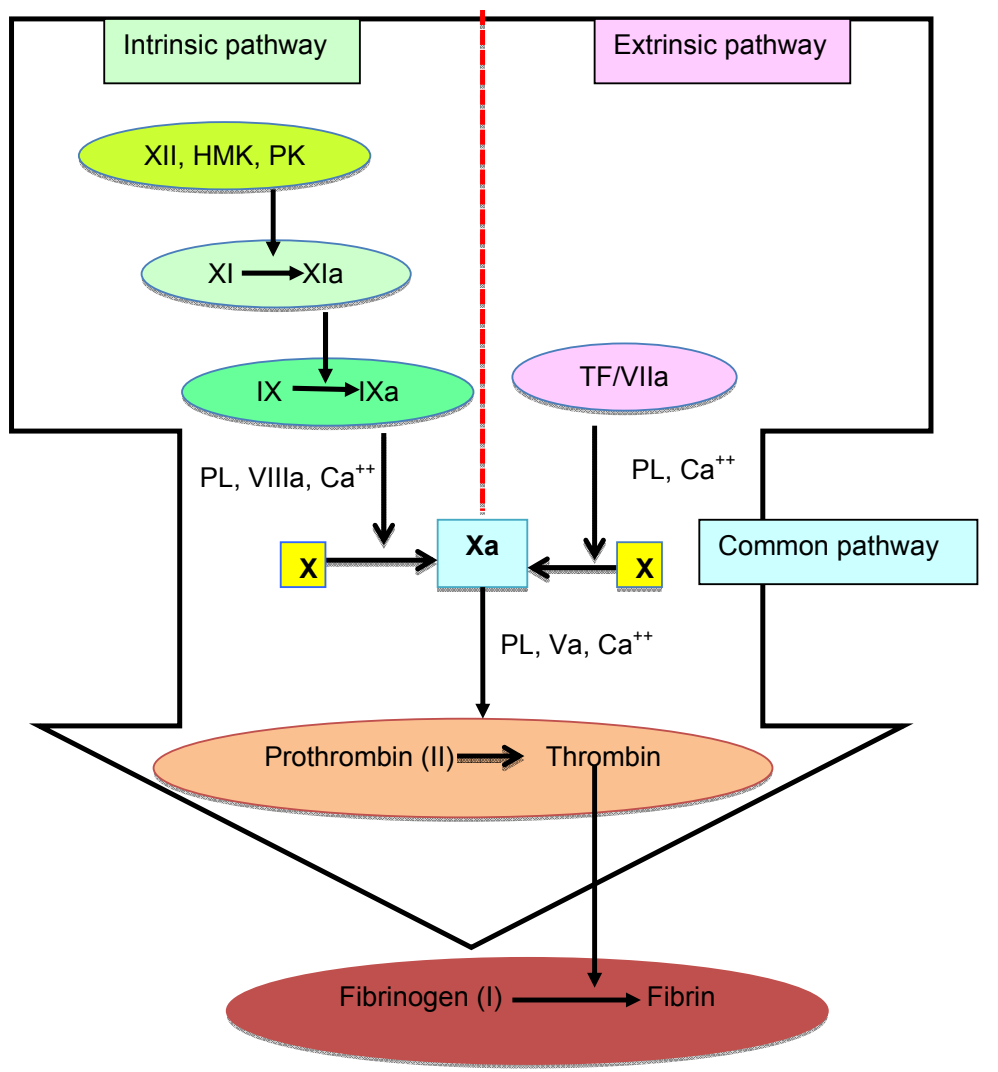

Adapted from "Hoffman M, Monroe DM, 3rd (2001). A cell-based model of hemostasis. Thromb Haemost 85(6):958-65"

Fig. 1. Early coagulation cascade. 
of intrinsic and extrinsic pathways is considered independent. (13)

While this concept was a huge achievement in the understanding of molecular interactions regulating coagulation, it had several limitations in explaining the hemostatic process in vivo. Thus, several new theories were proposed: one that extrinsic and intrinsic pathways are actually working inter-dependently has been well-received. (12) An example of this collaboration of two pathways is that the f.VIIa/TF complex from the extrinsic pathway can activate f.IX in the intrinsic pathway as well as f.X in the common pathway. (14) These concepts generated a new paradigm advocating that cellular components are the key players in coagulation which is controlled by the expression of a variety of cell features and protein receptors that localize the components of coagulation on specific cell surfaces. Thus, a concept of coagulation evolved from a mechanism being controlled by kinetics of various proteins to a new concept of cellular components controlling the coagulation process. (12) We now review the new, cell-based coagulation model.

\section{Concepts on the new, cell-based coagulation model}

The new model of coagulation is a well-coordinated series of cell activation, culminating in a blood clot. (12) Three stages proposed in this new coagulation models are initiation, amplification (priming) and propagation. In the initiation stage, $\mathrm{TF}$ from fibroblasts (or other $\mathrm{TF}$ bearing cells such as monocytes or endothelial cells) binds the activated factor VII, (a circulating coagulation factor) and forms the TF/VIIa complex. TF/VIIa complex in turn activates factors IX and X. The activated factor $\mathrm{X}(\mathrm{Xa})$ forms a $\mathrm{Xa} / \mathrm{Va}$ complex on the surface of fibroblasts and generates a sufficient amount of thrombin to induce platelet activation. (15) Thus, coagulation now moves to a more efficient site, the negatively charged, platelet surface.

In the second stage, the amplification (or priming) phase, the coagulation now has moved from tissue factor bearing fibroblasts to platelets that are much better suited for the coagulation with their negatively charged surfaces. Platelets adhere and accumulate cofactors on their surface and amplify the coagulation. Platelets and coagulation factors are activated by thrombin, which in turn binds and cleaves platelet protease-activated receptors (PAR1 and PAR4), triggering a complex signaling cascade. Furthermore, thrombin activates factors V, VIII, and XI also. (15) This is a crucial point many health care professionals are concerned about, because multifaceted anticoagulation ability will complicate the reversal process if excessive hemorrhage occurs. (16) In the final propagation phase, the tenase (factor "ten" activator) and prothrombinase (f.Xa / f.Va) complexes are assembled on the platelet surface, and large-scale thrombin generation takes place. (12) Tenase can originate from either the extrinsic pathway or from the intrinsic pathway. Intrinsic tenase is made of f.IXa and $\mathrm{f}$. VIIIa with $\mathrm{Ca}++$ and extrinsic tenase consists of $\mathrm{TF} / \mathrm{f}$. VIIa with $\mathbf{C a}++$. Intrinsic tenase is 50 times more efficient than extrinsic tenase in f.Xa expression. Additionally, prothrombinase complex (f.Xa / f.Va) is protected from tissue factor inhibitors, for it does not contain TF and thus a powerful production of f.Xa and thrombin formation results. This leads to a large scale fibrin formation. (15) These progressive phases are summarized in figure 2.

Under normal conditions, tissue factors do not come into contact with circulating vascular clotting factors. However, in some instances such as percutaneous coronary intervention, hemodialysis, or cardiac valve replacement surgery, these two components come into contact resulting in a clot and subsequent adverse outcomes, such as myocardial infarction or stroke. In various inflammatory states, TF expression can also be up-regulated in monocytes and endothelial cells by bacterial antigens, inflammatory cytokines, (17) or tumor necrosis factor. (18) This explains the hyper-coagulative state accompanying infection. Now that we have reviewed both old and new coagulation models, it will be easier to understand where the new antithrombotic drugs inhibit the coagulation mechanism.

\section{New antithrombotic agents}

\section{3-1. New antiplatelet drugs}

Platelets play a central role in thromboembolic (TE) events and four potential receptors have been recognized in platelet activation. (19)

The first pathway via the thromboxane A2 synthesis is through which the conventional antiplatelet agent, aspirin, exerts its antiplatelet action. Aspirin is a cyclooxygenase (COX)-1 inhibitor that irreversibly inhibits platelet activation. It is an efficient and inexpensive drug but cause mucosal irritation and may cause internal bleeding. Thus, in recent years, a group of new antiplatelet agents has been developed.

The second pathway includes thienopyridines that include clopidogrel $\left(\right.$ Plavix $\left.^{\circledR}\right)$, and prasugrel $\left(\right.$ Effient $\left.^{\circledR}\right)$ that irreversibly block adenosine diphosphate (ADP) activation of platelets through the ADP receptor P2Y12. (20) A non-thienopyridine $\mathrm{P} 2 \mathrm{Y} 12$ receptor inhibitor, ticagrelor $\left(\right.$ Ticlid $\left.^{\circledR}\right)$ is a reversible anti-platelet agent much more potent and has faster onset of action than clopidogrel. However, it accompanies more adverse effects such as dyspnea, hematoma and excessive bleeding. (21) The third pathway is via von Willebrand factor (vWF) and platelets' glycoprotein (Gp)-Ib receptor. When rupture of an atherosclerotic plaque exposes collagen and vWF, the A1 domain of vWF binds to the Gp-Ib receptor of 


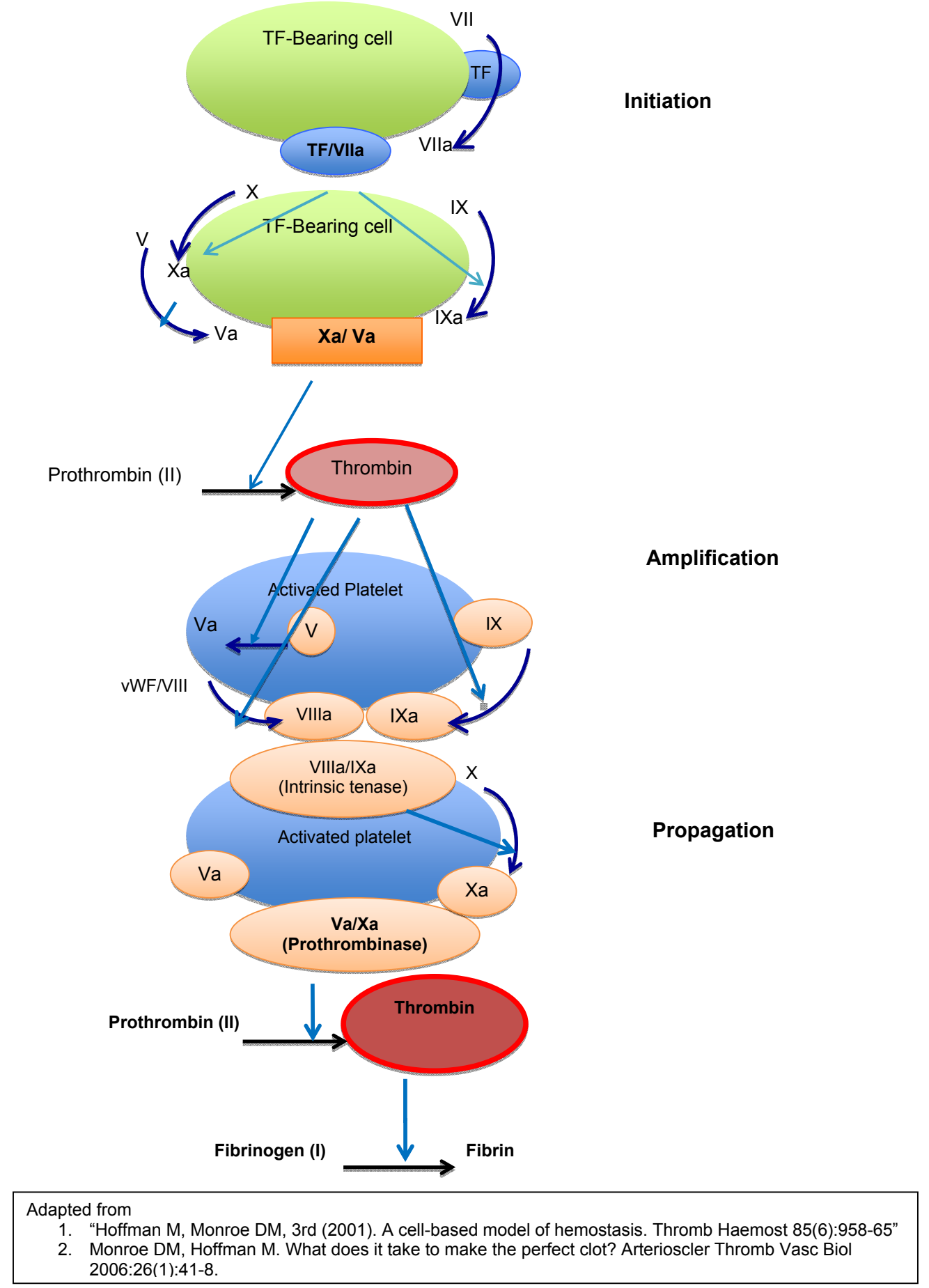

Fig. 2. New cell-based coagulation model.

platelet. The fourth pathway for platelet activation is via protease activator receptor-1 (PAR-1). If platelet activation is blocked through any one of these pathways, platelet membrane glycoprotein IIa/IIIb cannot bind to fibrinogen and unable to generate a hemostatic plug.
(22) These four pathways through which platelet aggregation can be inhibited are illustrated in figure 3 .

3-2. New direct oral anticoagulants (DOAs)

The conventional vitamin $\mathrm{K}$ antagonist (VKA), warfarin, has several drawbacks that limit its clinical util- 

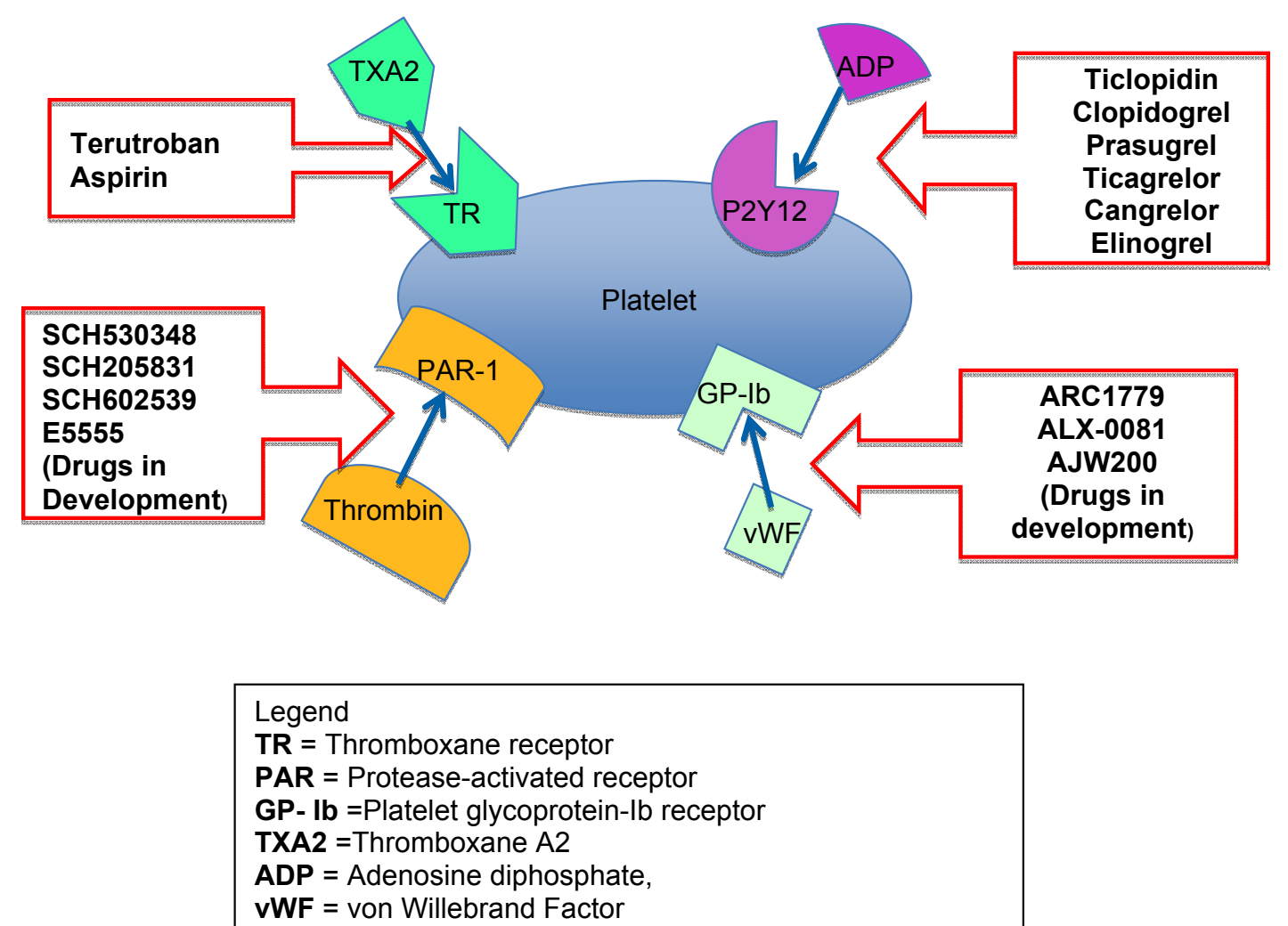

Adapted from "Siller-Matula JM, Krumphuber J, Jilma B (2010). Pharmacokinetic, pharmacodynamic and clinical profile of novel antiplatelet drugs targeting vascular diseases. $\mathrm{Br} J$ Pharmacol 159(3):502-17."

Fig. 3. Pathways of antiplatelet mode of action.

ity: numerous drug-drug and drug-food interactions, the genetic differences in VKA metabolism via cytochrome P450, and wide inter-individual differences in pharmacokinetics as well as the narrow therapeutic window which requires frequent testing. Therefore, patients' compliance directly affects its clinical efficacy. Warfarin stays in the therapeutic range approximately $60 \%$ of the time, with an average of $\sim 12 \%$ of the time in the supra- and $\sim 20 \%$ of the time in the sub-therapeutic range. (23) For these reasons, the impetus for development of safer anticoagulants has been active resulting in several new direct oral anticoagulants (DOAs). These are direct factor Xa inhibitors rivaroxaban $\left(\right.$ Xarelto $\left.^{\circledR}\right)$, apixaban (Eliquis ${ }^{\circledR}$ ), edoxaban and direct thrombin inhibitor dabigatran $\left(\operatorname{Pradaxa}^{\circledR}\right)$. (Tables 2,3) summarizes the pharmacokinetics pharmacodynamics, including dietary potentiators or inhibitors of new DOAs as well as warfarin.

New DOAs have rapid onset of action, fast elimination on cessation and have fewer drug-drug or drug-food in- teractions. This obviates the need for frequent testing as with warfarin. However, no reversal agents are available at present and minimal trauma such as subgingival periodontal scaling, gingivectomy, or simple exodontia have potential to become serious hemorrhagic events. We will discuss the new direct oral anticoagulants in detail.

3-2-a. Direct factor Xa inhibitors (Xaban)

Rivaroxaban is one of the direct factor Xa (f.Xa) inhibitors approved by FDA for the prevention of thromboembolic (TE) events in patients with atrial fibrillation.(24) The other drug in this group is apixaban for which FDA just approved its use in Jan. 2013. These drugs inhibit both free f.Xa and bound f.Xa within the prothrombinase complex. Rivaroxaban reaches its peak plasma level at $\sim 3$ hours after administration and $\sim 65 \%$ is excreted via urine and $\sim 35 \%$ via biliary and fecal routes. Therefore, in the elderly or in persons with renal impairment, rivaroxaban would have a prolonged half-life.

3-2-b. Direct thrombin inhibitor (DTI)

Dabigatran is one of the direct thrombin inhibitors (cf. 
Table 2. Pharmacokinetics of warfarin and new direct oral anticoagulants.

\begin{tabular}{|c|c|c|c|c|c|}
\hline & $\begin{array}{l}\text { Vitamin K } \\
\text { Antagonist }\end{array}$ & $\begin{array}{l}\text { Direct Xa } \\
\text { inhibitors }\end{array}$ & $\begin{array}{l}\text { Direct thrombin } \\
\text { inhibitors }\end{array}$ & Cox-1 inhibitors & $\begin{array}{l}\text { P2Y12 ADP } \\
\text { receptor } \\
\text { inhibitors }\end{array}$ \\
\hline Drug names & Warfarin & $\begin{array}{l}\text { Rivaroxaban, } \\
\text { apixaban }\end{array}$ & Diabigatran $^{3}$ & Aspirin $^{3}$ & $\begin{array}{l}\text { Clopidogrel, } \\
\text { Ticlopidine, } \\
\text { Prasugrel }\end{array}$ \\
\hline $\begin{array}{l}\text { Peak of action } \\
\left(t_{\max }\right)\end{array}$ & 4-5 days & 1-3 hrs. & $1-3$ hrs. & $0.5-4$ hrs. & $\begin{array}{l}3 \text { to } 7 \text { days for } \\
\text { Clop. } 1-3 \mathrm{hrs} \text {. } \\
\text { for others }\end{array}$ \\
\hline $\begin{array}{l}\text { Elimination } \\
\text { half-life }\left(\mathrm{t}_{1 / 2}\right)\end{array}$ & $36-42$ hrs. & 9-15 hrs. & $14-17$ hrs. $^{3}$ & $15-30 \mathrm{~min}$ & $\begin{array}{l}24 \text { to } 36 \mathrm{hrs} \text { for } \\
\text { Ticlid, } 7-8 \mathrm{hrs} \\
\text { for others. }\end{array}$ \\
\hline $\begin{array}{l}\text { Metabolized } \\
\text { via CYP? }\end{array}$ & Yes & $\begin{array}{l}\text { Yes (CYP3A4, } \\
\text { CYP2J2 and more) }\end{array}$ & Minor & Minor & $\begin{array}{l}\text { Yes (CYP2C19 } \\
\text { and CYP3A4 } \\
\text { and more) }\end{array}$ \\
\hline $\begin{array}{l}\text { Route of } \\
\text { elimination }\end{array}$ & Renal and bile & $\begin{array}{l}65 \% \text { renal } \\
35 \% \text { fecal }\end{array}$ & $\begin{array}{l}80 \% \text { renal } \\
20 \% \text { fecal }\end{array}$ & Mostly renal & $\begin{array}{l}54 \% \text { renal } \\
46 \% \text { fecal }\end{array}$ \\
\hline $\begin{array}{l}\text { Interaction } \\
\text { with other } \\
\text { drugs and } \\
\text { food }\end{array}$ & $\begin{array}{l}\text { Genetics* } \\
\text { Potentiators' } \\
\text { Ciprofloxacin; } \\
\text { Cotrimoxazole; } \\
\text { Erythromycin; } \\
\text { Azithromycin; } \\
\text { Fluconazole; } \\
\text { Isoniazid; } \\
\text { Metronidazole; } \\
\text { Amiodarone; } \\
\text { Clofibrate; } \\
\text { Diltiazem; } \\
\text { Fenofibrate; } \\
\text { Propafenone; } \\
\text { Propranolol; } \\
\text { Phenybutazone; } \\
\text { Piroxicam; } \\
\text { Cimetidine; } \\
\text { Omeprazole; } \\
\text { Fish oil; } \\
\text { Mango. } \\
\text { Inhibitors } \\
\text { Griseofulvin; } \\
\text { Nafcillin; } \\
\text { Ribavirin; } \\
\text { Rifampin; } \\
\text { Barbiturates; } \\
\text { Carbamazepine; } \\
\text { Cholestyramine; } \\
\text { Foods with high } \\
\text { Vitamin K, such } \\
\text { as Avocado, Kale. }\end{array}$ & $\begin{array}{l}\text { Potentiators }^{2} \\
\text { Itraconazole; } \\
\text { Voriconazole; } \\
\text { Posaconazole; } \\
\text { Ritonavir; } \\
\text { Clarithromycin; } \\
\text { Naproxen; } \\
\text { Anticoagulants. } \\
\text { Inhibitors } \\
\text { Rifampicin; } \\
\text { St. John Wort; } \\
\text { Phenytoin; } \\
\text { Carbamazepine ; } \\
\text { Phenobarbital. }\end{array}$ & $\begin{array}{l}\text { Potentiators }^{2} \\
\text { Amiodarone; } \\
\text { Verapamil; } \\
\text { Quinidine; } \\
\text { Digoxin; } \\
\text { Ketoconazole; } \\
\text { Clarithromycin; } \\
\text { Aspirin; } \\
\text { Clopidrogrel; } \\
\text { Diclofenac; } \\
\text { Inhibitors } \\
\text { Antacids; } \\
\text { Pantoprazole; } \\
\text { Rifampin; } \\
\text { St. John Wort. }\end{array}$ & $\begin{array}{l}\text { Potentiators } \\
\text { Other } \\
\text { Anticoagulants; } \\
\text { SSRIs; } \\
\text { Alcohols; } \\
\text { Enalapril; } \\
\text { Inhibitors } \\
\text { Indomethacin; } \\
\text { ibuprofen; } \\
\text { naproxen. }\end{array}$ & $\begin{array}{l}\text { Potentiators } \\
\text { Phenytoin; } \\
\text { Tamoxifen; } \\
\text { Tolbutamide; } \\
\text { Fluvastatin; } \\
\text { Other } \\
\text { anticoagulants. } \\
\text { Inhibitors: } \\
\text { Omeprazole; }\end{array}$ \\
\hline
\end{tabular}

- CYP: cytochrome P-450.

- ${ }^{*} \mathrm{CY} 2 \mathrm{C} 9 * 3$ allele may be associated with retarded elimination of (S)-warfarin and may increase the clinical effects.

- Interaction is a partial list of only highly probable interaction. Many probable, possible interactions are reported. In reference $\dagger$

- SSRIs: selective serotonin reuptake inhibitors

References for Table 2:

1 Ansell, J., Hirsh, J., Hylek, E., Jacobson, A., Crowther, M., Palareti, G. \& American College of Chest, P. (2008) Pharmacology and management of the vitamin K antagonists: American College of Chest Physicians Evidence-Based Clinical Practice Guidelines (8th Edition). Chest 133, 160S-198SVKA

2 Nutescu, E., Chuatrisorn, I. \& Hellenbart, E. (2011) Drug and dietary interactions of warfarin and novel oral anticoagulants: an update. J Thromb Thrombolysis 31, 326-343

3 Hohlfeld, T., Zimmermann, N., Weber, A. A., Jessen, G., Weber, H., Schror, K., Holtje, H. D. \& Ebel, R. (2008) Pyrazolinone analgesics prevent the antiplatelet effect of aspirin and preserve human platelet thromboxane synthesis. J Thromb Haemost 6, 166-173.

4 Mackenzie, I. S., Coughtrie, M. W., MacDonald, T. M. \& Wei, L. (2010) Antiplatelet drug interactions. J Intern Med 268, 516-529. 
Table 3. Table of abbreviations

\begin{tabular}{|c|c|}
\hline Abbreviation & Definition \\
\hline aPPT & activated Partial Thromboplastin Time \\
\hline ADP & Adenosine Diphosphate \\
\hline ATIII & Antithrombin III \\
\hline $\mathrm{CBC}$ & Complete Blood Count \\
\hline COX & cyclooxygenase \\
\hline DTI & Direct Thrombin Inhibitor \\
\hline Extrinsic tenase & tissue factor + f.VIIa $+\mathrm{Ca}^{++}$ \\
\hline f.V or $\mathrm{V}$ & Factor V \\
\hline f.VII or VII & Factor VII \\
\hline f.VIII or VIII & Factor VIII \\
\hline f.IX or IX & Factor IX \\
\hline f.X or X & Factor X \\
\hline f.XI or XI & Factor XI \\
\hline f.XII or XII & Factor XII \\
\hline f.Va or $\mathrm{Va}$ & activated Factor V \\
\hline f.VIIa or VIIa & activated Factor VII \\
\hline f.VIIIa or VIIIa & activated Factor VIII \\
\hline f.IXa or IXa & activated Factor IX \\
\hline f.Xa or Xa & activated Factor $\mathrm{X}$ \\
\hline f.XIa or XIa & activated Factor XI \\
\hline Fibrinogen & Factor I \\
\hline Fibrin & Factor Ia \\
\hline FDA & Food and Drug Administration \\
\hline HIT & Heparin Induced Thrombocytopenia \\
\hline HMK & High Molecular weight Kininogen \\
\hline INR & International Normalized Ratio \\
\hline Intrinsic tenase & f. IXa + f. VIIIa $+\mathrm{Ca}^{++}$ \\
\hline LMWH & Low Molecular Weight Heparin \\
\hline $\mathrm{OA}$ & Oral Anticoagulant \\
\hline PAR & Protease-Activated Receptors \\
\hline PF4 & Platelet Factor 4 \\
\hline PK & Prekallikrein \\
\hline Prothrombin & Factor II \\
\hline Prothrombinase & $\mathrm{f} . \mathrm{Xa}+\mathrm{f} . \mathrm{Va}+\mathrm{Ca}^{++}$ \\
\hline PT & Prothrombin Time \\
\hline PTT & Partial Thromboplastin time \\
\hline $\mathrm{T}$ & Thrombin \\
\hline Thrombin & f.IIa (activated Factor II) \\
\hline TF & Tissue Factor \\
\hline TFPI & Tissue factor pathway inhibitor \\
\hline UFH & Unfractioned Heparin \\
\hline vWF & von Willebrand factor \\
\hline
\end{tabular}

to Figs. 1,2) approved by FDA for stroke prevention in non-valvular atrial fibrillation (A-fib). (25) It has a halflife of $14-17$ hours and $80 \%$ is excreted through urine and $20 \%$ through the fecal route. Therefore, in persons with impaired renal function, the half-life will increase and invasive procedures that require cessation of dabigatran should be determined according to renal function. (26) Although reliable pharmacodynamics and pharmacokinetics eliminate frequent testing and ecarin clotting time (ECT) and thrombin clotting time (TT) assays may assess antithrombotic action of new DOAs, there is no dependable way of determining therapeutic plasma levels of dabigatran. (27) Neither aPTT, PT nor
INR is sufficiently precise to measure the clinically effective serum level of DOAs. (28)

Not as extensive as warfarin, some drug-drug interactions have been demonstrated with dabigatran: with quinidine, ketoconazole, amiodarone, and verapamil that can increase the dabigatran plasma concentrations. (26) Co-administration of other anticoagulants or nonsteroidal anti-inflammatory drugs will also increase dabigatran level. On the other hand, rifampicin and some proton pump inhibitors such as omeprazole will decrease dabigatran levels.

\section{Clinical implications of the new anticoagulants}

Currently, there is no published research evidence utilizing new DOAs in the dental setting. However, we summarized perioperative strategies that appeared in medical journals so that dental professionals will have adequate basic knowledge when they consult physicians regarding their patients on new DOAs. In addition, active research in the development of the antidotes for new DOAs makes it imperative for dental professionals to have a clear understanding of coagulation mechanisms. 4-1. General dental considerations

Scheduling early in the week and early morning of the day appointment may be necessary to afford additional visit in case of excessive bleeding. Furthermore, additional supplies to deal with the post-surgical bleeding should be considered for patients taking anticoagulants. $(4,29,30)$ Some suggested additional supplies are absorbable hemostatic dressings such as oxidised cellulose $\left(\right.$ Surgicel $\left.{ }^{\circledR}\right)$, collagen sponge (Haemocollagen ${ }^{\circledR}$ ) or resorbable gelatin sponge $\left(\right.$ Spongostan $\left.^{\circledR}\right)$, along with resorbable and non- resorbable sutures. Also suturing the extraction sites and pressure application with gauzes saturated with tranexamic acid has also been suggested to prevent post-surgical bleeding. (31)

Careful pre-operative assessment of patients' medical profile was a common recommendations and some suggested routine laboratory studies including: a complete blood count (CBC), prothrombin time (PT), activated partial thromboplastin time (aPTT), INR in case of VKA, and bleeding time. Arranging an after-hours response team should be considered for those general dental practitioners (GDPs) without hospital privileges to counter post-operative bleeding. Most bleeding risk studies compared those who stopped warfarin to those who stayed on warfarin during the dental procedures and found that bleeding was not significantly different. However, if the bleeding incidence was compared to the controls not taking warfarin, the indirectly calculated relative bleeding risk was about a 10 -fold increase in those who are on warfarin (9-10\%) than those who do not take anticoagulants (1\%). (32) In addition, some delayed bleedings were reported after 24 or 48 hours. (33) Therefore, post-surgical bleeding in patients taking 
anticoagulants is much greater than what is expected in the general dentist's office (GDPs) and setting up an effective post-surgical response plan will be necessary. As to the risk factors for post-dental surgical bleeding, we postulated that (a) the severity of systemic morbidity requiring a high degree of anticoagulation, (b) co-morbidity such as renal insufficiency and hepatic dysfunction, and (c) the surgical trauma involved in dental procedures may all influence the bleeding risk. However, there is no clear definition of significant bleeding in the dental setting or clear guidelines for dental procedures with high bleeding risk. We reviewed the definition of significant bleeding by several authors and found Lockhart and colleague's definition is the most reasonable. (34) They defined significant bleeding as:

1) Continues beyond 12 hours; (However,) in our opinion, even bleeding that continues to 5-6 hours should be considered significant.

2) Causes the patient to call, return to the dental practitioner, or visit the emergency department;

3) Results in the development of a large hematoma or ecchymosis within the oral or adjacent soft tissues;

4) Requires a blood transfusion or other blood products. As for the determination of invasiveness of dental procedures, Muthukrishnan et al. surveyed general dental practitioners (GDPs) and found that $71 \%$ of the GDPs surveyed considered subgingival debridement as a high bleeding risk, $48 \%$ inferior alveolar block, and 32\% subgingival restoration as high bleeding risks. (35) For exodontia, single and up to 3 extractions were considered a minor bleeding risk.

4-2. Managing patients on anticoagulants in dentalsurgical setting

Recent American College of Chest Physicians' (ACCP) Evidence-Based Clinical Practice Guidelines reflects the controversy surrounding the withdrawal/continuation of vitamin $\mathrm{K}$ antagonists (VKAs) and modified the past recommendation: In dental procedures with low bleeding risk, VKAs may be continued with implementation of local haemostatic measures or may be interrupted for 2-3 days prior to surgery. (28) However, most dental professionals favor continuing VKAs when International Normalized Ratio (INR) is below 3.5. As Ball emphasized (36) (1) consulting the prescribing physician(s) to ascertain the patient's medical status that required anticoagulation therapy, (2) checking the latest INR and testing it again on the day of the dental procedure may be very important in preventing thromboembolic (TE) events because VKA levels fluctuate with diet and patient's compliance. If INR $>3.5$ with moderate bleeding risk, withdrawal of VKA with physician's approval for 2-3 days may be necessary. Also hemostatic measures described in section 4-1 should be employed. In high bleeding risk procedures including periodontal surgery, surgical extraction, multiple ex- tractions ( $>3$ teeth), osteoplasty, and extensive head and neck surgery, a withdrawal of VKA in conjunction with subcutaneous or intravenous heparin usage was recommended. (36) This protocol is illustrated in figure 4.

The withdrawal of new DOAs protocol is more complex than VKA because no simple reversal agents are available. The protocol is governed by the half-life of the drug, invasiveness of the (dental) procedures, the patients' co-morbidities, and TE risks. As the elimination half-life of dabigatran is 12-18 hours, if the bleeding risk is high, the last dose should be given 3 days prior to the surgery (skip for 2 days). (28) If moderate hemostasis is acceptable, the last dose should be given -2 days (skipping 1 day). In case of moderate renal impairment, namely creatinine clearance is $(\mathrm{CrCl}) 30-50 \mathrm{~mL} / \mathrm{min}$, skip 4 doses (skip for 2 days) for low bleeding risk procedures and 6-8 doses (skip 3-4 days) for high bleeding risk procedures. $(28,37)$ For rivaroxaban with half-life of 29-10 hours, the renal function is less critical in drug elimination. Thus, the last dose should be given on -2 days for the low bleeding risk and on -3 days for high bleeding risk procedures respectively. Another factor that should be considered is the individual patients TE risk. If TE risk is high, bridging with heparin(s) without overlapping with DOAs is suggested. The perioperative protocols for DOAs are summarized in figure 5 .

For the antiplatelet agents, the perioperative protocol is similar to the other antithrombotics. If the bleeding risk of procedure is low, not stopping the antiplatelet is recommended. (37) Resumption of aspirin results in nearly immediate maximal drug effects. However clopidogrel will take almost 7 days to reach the maximal effective level. Administering the initial loading dose may shorten this lag period (37).

4-3. Reversal of direct oral anticoagulants

Although new DOAs have the advantage of stable pharmacological action and less interaction with foods or other drugs, the most important disadvantage of these new drugs is the lack of specific reversal agents. In case of excessive bleeding, the knowledge of reversal strategy will empower dental professionals.

In case of warfarin-related major bleeding, vitamin $\mathrm{K}$ may be administered. However, it takes almost 24 hours to bring INR to normal range. Therefore, in urgent hemorrhage caused by VKA over-dose, nonspecific prohemostatic agents, such as prothrombin complex concentrates (PCCs), are indicated. (38)

The first line of defense in any bleeding is discontinuation of the causative medication and utilization of local measures such as pressure with tranexamic acid-soaked gauzes, or other hemostatic products. If DOA administration is recent, gastric lavage or activated charcoal can be effective. (38) If these measures fail, hemodialysis or administration of either 3-factor (II, IX, and X) or 4-factor (II, VII, IX, and X) PCC should be considered. 


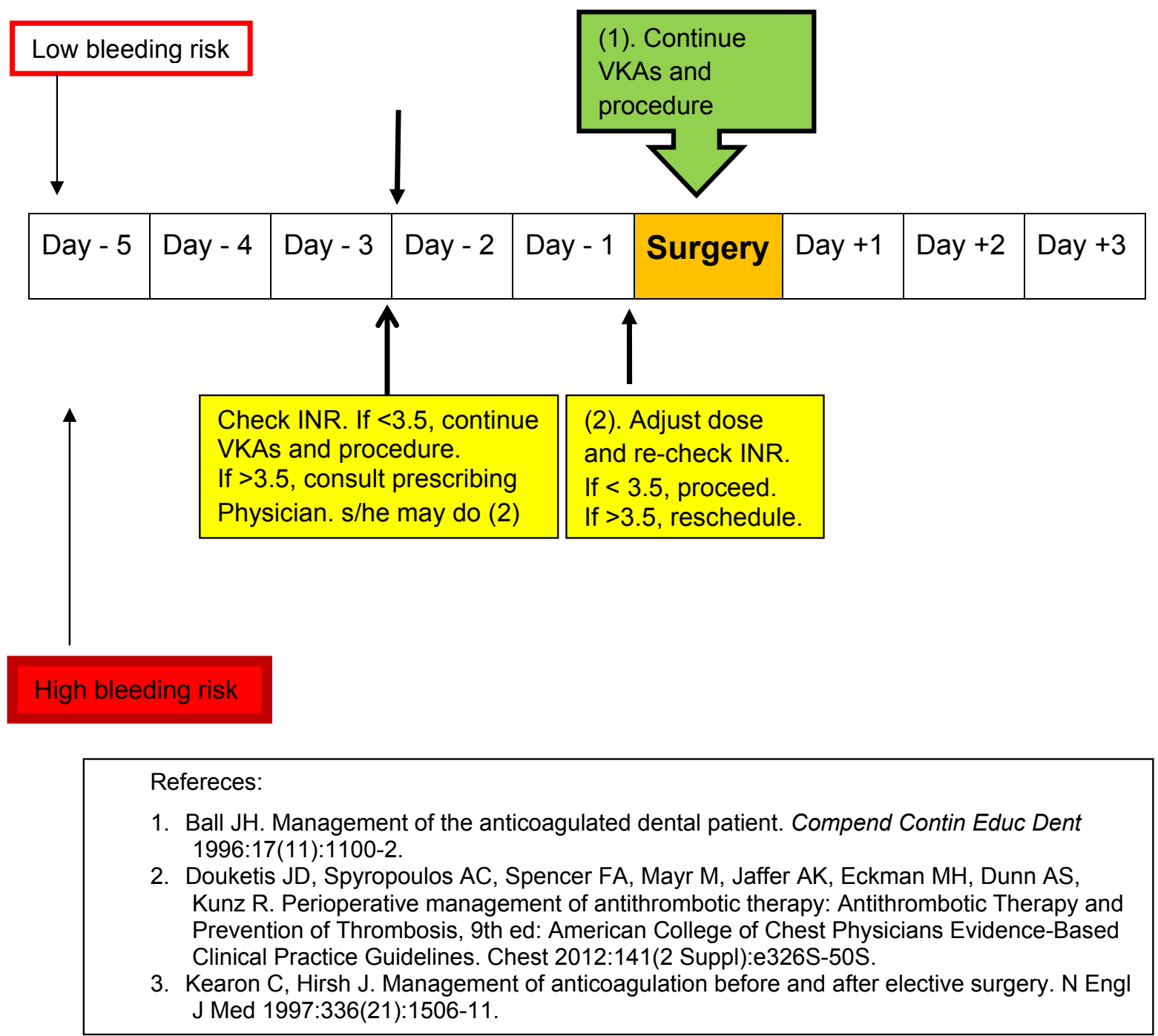

Fig. 4. Perioperative management strategies for Vitamin K antagonists.

Also in the murine model, fresh frozen plasma (FFP) was able to reduce hemorrhage. However, due to the inconvenience of thawing FFP, PCCs or recombinant factor VIIa (rFVIIa) is gaining popularity over FFP.

Ex vivo trial in humans also showed that activated four factor PCC reversed the effects of rivaroxaban and dabigatran. $(39,40)$ In the U.S., unactivated 4- factor PCCs are not available but activated PCCs that contain similar concentrations of non-activated factors II, IX, and $\mathrm{X}$ and activated factor VII are available. PCC has been used in the dental setting successfully. (41) However, caution must be exercised in using PCC or rFVIIa because they carry thrombogenic risks.

\section{Conclusion}

Although the rate of thromboembolic events is low, (approximately $0.5 \%)$ in the dental setting $(42,43)$, most dental professionals favor continuing VKAs (warfarin) for dental surgery because the adverse outcomes of discontinuation are much more serious than bleeding risks. However, the emergence of new direct oral anticoagulants poses some challenges due to the lack of simple reversal agent in the event of post-surgical bleeding. Future randomized trials utilizing new direct oral anticoagulants like the direct factor Xa inhibitors or direct thrombin inhibitors are warranted. 


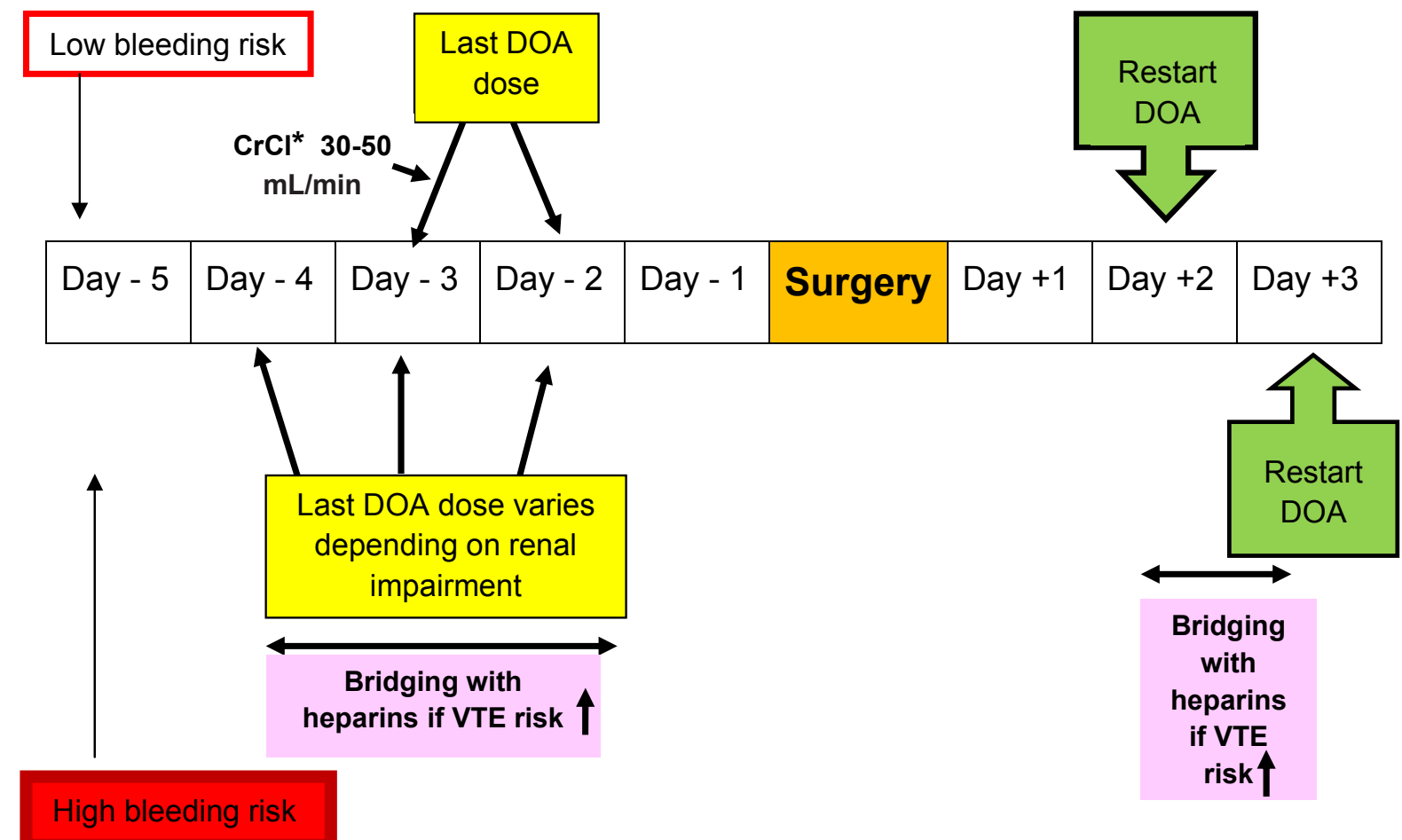

Modified from:

1. Douketis JD et al. (2012). Perioperative Management of Antithrombotic Therapy: Antithrombotic Therapy and Prevention of Thrombosis, 9th ed: American College of Chest Physicians EvidenceBased Clinical Practice Guidelines. Chest 141:

2. Sie $\mathrm{P}$ et al. Recommendations of the Working Group on Perioperative Haemostasis and the French Study Group on Thrombosis and Haemostasis. Arch Cardiovasc Dis. 2011;104(12):669-676.

- Upper section for low bleeding risk strategy

- Lower section for high bleeding risk strategy Legend

*CrCl: creatinine clearance DOA: direct oral anticoagulants VTE: venous thromboembolism

NB: This strategy is for the purpose of understanding the principle. The actual implementation will be executed by the prescribing physician(s).

Fig. 5. Perioperative management strategies for Direct Oral Anticoagulants.

\section{References}

1. Institute of Medicine (US) Committee on Preventing the Global Epidemic of Cardiovascular Disease: Meeting the Challenges in Developing Countries; Fuster V, Kelly BB, editors. Promoting Cardiovascular Health in the Developing World: A Critical Challenge to Achieve Global Health. Washington (DC): National Academies Press (US); 2010. 2. Kosyfaki P, Att W, Strub JR. The dental patient on oral anticoagulant medication: a literature review. J Oral Rehabil. 2011;38:615-33.

3. Lip GY, Tse HF, Lane DA. Atrial fibrillation. Lancet. 2012;379:648-61.

4. Aframian DJ, Lalla RV, Peterson DE. Management of dental patients taking common hemostasis-altering medications. Oral Surg Oral Med Oral Pathol Oral Radiol Endod. 2007;103 Supp145:e1-11.

5. Devani P, Lavery KM, Howell CJ. Dental extractions in patients on warfarin: is alteration of anticoagulant regime necessary? $\mathrm{Br} \mathrm{J}$ Oral Maxillofac Surg. 1998;36:107-11.

6. Madrid C, Sanz M. What influence do anticoagulants have on oral implant therapy? A systematic review. Clin Oral Implants Res. 2009;20 Supp14:96-106.

7. Nematullah A, Alabousi A, Blanas N, Douketis JD, Sutherland SE. Dental surgery for patients on anticoagulant therapy with warfarin: a systematic review and meta-analysis. J Can Dent Assoc. 2009;75:41. 8. Firriolo FJ, Hupp WS. Beyond warfarin: the new generation of oral anticoagulants and their implications for the management of dental patients. Oral Surg Oral Med Oral Pathol Oral Radiol Endod. 2012;113:431-41.

9. Little JW. New oral anticoagulants: Will they replace warfarin? Oral Surg Oral Med Oral Pathol Oral Radiol. 2012;113:575-80. 
10. Davie EW, Kirby EP. Molecular mechanisms in blood coagulation. Curr Top Cell Regul. 1973;7:51-86.

11. Macfarlane RG. A clotting scheme for 1964. Thromb Diath Haemorrh Suppl. 1965;17:45-52.

12. Hoffman M, Monroe DM. A cell-based model of hemostasis. Thromb Haemost. 2001;85:958-65.

13. Adams RL, Bird RJ. Review article: Coagulation cascade and therapeutics update: relevance to nephrology. Part 1: Overview of coagulation, thrombophilias and history of anticoagulants. Nephrology (Carlton). 2009;14:462-70.

14. Osterud B, Rapaport SI. Activation of factor IX by the reaction product of tissue factor and factor VII: additional pathway for initiating blood coagulation. Proc Natl Acad Sci U S A. 1977;74:5260-4.

15. Howard EL, Becker KC, Rusconi CP, Becker RC. Factor IXa inhibitors as novel anticoagulants. Arterioscler Thromb Vasc Biol. 2007;27:722-7.

16. Harper P, Young L, Merriman E. Bleeding risk with dabigatran in the frail elderly. N Engl J Med. 2012;366:864-6.

17. Schecter AD, Rollins BJ, Zhang YJ, Charo IF, Fallon JT, Rossikhina $\mathrm{M}$, et al. Tissue factor is induced by monocyte chemoattractant protein-1 in human aortic smooth muscle and THP-1 cells. J Biol Chem. 1997;272:28568-73.

18. Conway EM, Bach R, Rosenberg RD, Konigsberg WH. Tumor necrosis factor enhances expression of tissue factor mRNA in endothelial cells. Thromb Res. 1989 ;53:231-41.

19. Siller-Matula JM, Krumphuber J, Jilma B. Pharmacokinetic, pharmacodynamic and clinical profile of novel antiplatelet drugs targeting vascular diseases. Br J Pharmacol. 2010;159:502-17.

20. Mills DC, Puri R, Hu CJ, Minniti C, Grana G, Freedman MD, et al. Clopidogrel inhibits the binding of ADP analogues to the receptor mediating inhibition of platelet adenylate cyclase. Arterioscler Thromb. 1992;12:430-6.

21. Becker RC, Bassand JP, Budaj A, Wojdyla DM, James SK, Cornel $\mathrm{JH}$, et al. Bleeding complications with the $\mathrm{P} 2 \mathrm{Y} 12$ receptor antagonists clopidogrel and ticagrelor in the PLATelet inhibition and patient Outcomes (PLATO) trial. Eur Heart J. 2011;32:2933-44.

22. McNicol A, Israels SJ. Platelets and anti-platelet therapy. J Pharmacol Sci. 2003;93:381-96.

23. Deedwania PC, Huang GW. Role of emerging antithrombotic therapy in the prevention of cardioembolic complications in patients with atrial fibrillation. Am J Cardiovasc Drugs. 2011;11:265-75.

24. Hankey GJ, Patel MR, Stevens SR, Becker RC, Breithardt G, Carolei A, et al. Rivaroxaban compared with warfarin in patients with atrial fibrillation and previous stroke or transient ischaemic attack: a subgroup analysis of ROCKET AF. Lancet Neurol. 2012;11:315-22.

25. Connolly SJ, Ezekowitz MD, Yusuf S, Eikelboom J, Oldgren J, Parekh A, et al. Dabigatran versus warfarin in patients with atrial fibrillation. N Engl J Med. 2009;361:1139-51.

26. Hankey GJ, Eikelboom JW. Dabigatran etexilate: a new oral thrombin inhibitor. Circulation. 2011;123:1436-50.

27. Watanabe M, Qureshi AI, Siddiqui FM. Periprocedural management of patients on dabigatran etexilate treatment. AJNR Am J Neuroradiol. 2011;32:E166.

28. Douketis JD, Spyropoulos AC, Spencer FA, Mayr M, Jaffer AK, Eckman $\mathrm{MH}$, et al. Perioperative management of antithrombotic therapy: Antithrombotic Therapy and Prevention of Thrombosis, 9th ed: American College of Chest Physicians Evidence-Based Clinical Practice Guidelines. Chest. 2012;141 Supp12:e326S-50S.

29. Kassab MM, Radmer TW, Glore JW, Visotcky A, Robertson J, Degroot B. A retrospective review of clinical international normalized ratio results and their implications. J Am Dent Assoc. 2011;142:1252-7.

30. Scully C, Wolff A. Oral surgery in patients on anticoagulant therapy. Oral Surg Oral Med Oral Pathol Oral Radiol Endod. 2002;94:5764.

31. Bacci C, Maglione M, Favero L, Perini A, Di Lenarda R, Berengo $\mathrm{M}$, et al. Management of dental extraction in patients undergoing anticoagulant treatment. Results from a large, multicentre, prospective, case-control study. Thromb Haemost. 2010;104:972-5.
32. Eichhorn W, Burkert J, Vorwig O, Blessmann M, Cachovan G, Zeuch J, Eichhorn M, Heiland M. Bleeding incidence after oral surgery with continued oral anticoagulation. Clin Oral Investig. 2012;16:1371-6.

33. Brooks AS. Delayed complications of tooth extraction in patients taking warfarin, antibiotics, and other medications. J Oral Maxillofac Surg. 2011;69:977-9.

34. Lockhart PB, Gibson J, Pond SH, Leitch J. Dental management considerations for the patient with an acquired coagulopathy. Part 2: Coagulopathies from drugs. Br Dent J. 2003;195:495-501.

35. Muthukrishnan A, Bishop K. An assessment of the management of patients on warfarin by general dental practitioners in South West Wales. Br Dent J. 2003;195:567-70.

36. Ball JH. Management of the anticoagulated dental patient. Compend Contin Educ Dent. 1996;17:1100-2.

37. Ortel TL. Perioperative management of patients on chronic antithrombotic therapy. Blood. 2012;120:4699-705.

38. Kaatz S, Kouides PA, Garcia DA, Spyropolous AC, Crowther M, Douketis JD, et al. Guidance on the emergent reversal of oral thrombin and factor Xa inhibitors. Am J Hematol. 2012;87 Suppl1:S141-5.

39. Eerenberg ES, Kamphuisen PW, Sijpkens MK, Meijers JC, Buller HR, Levi M. Reversal of rivaroxaban and dabigatran by prothrombin complex concentrate: a randomized, placebo-controlled, crossover study in healthy subjects. Circulation. 2011;124:1573-9.

40. Marlu R, Hodaj E, Paris A, Albaladejo P, Crackowski JL, Pernod G. Effect of non-specific reversal agents on anticoagulant activity of dabigatran and rivaroxaban. A randomised crossover ex vivo study in healthy volunteers. Thromb Haemost. 2012;108:217-24.

41. Morimoto Y, Niwa H, Nakatani T. On the use of prothrombin complex concentrate in patients with coagulopathy requiring tooth extraction. Oral Surg Oral Med Oral Pathol Oral Radiol Endod. 2010;110:e7-10.

42. Akopov SE, Suzuki S, Fredieu A, Kidwell CS, Saver JL, Cohen $\mathrm{SN}$. Withdrawal of warfarin prior to a surgical procedure: time to follow the guidelines?. Cerebrovasc Dis. 2005;19:337-42.

43. Garcia DA, Regan S, Henault LE, Upadhyay A, Baker J, Othman $\mathrm{M}$, et al. Risk of thromboembolism with short-term interruption of warfarin therapy. Arch Intern Med. 2008;168:63-9.

\section{Acknowledgment \\ Funding Sources}

The funding sources listed below had no influence in our review. Dr. Meurman is supported by grants from The Finnish Medical Society and Helsinki University Central Hospital, EVO TYH 3245.

Dr. Baird is supported by NIH grants R01 EB010087 and R21 MH097639-01.

\section{Conflicts of interest}

None declared.

The abstract of this study has been presented at the "Boston University, School of Dental Medicine Science Day" on March 15 $5^{\text {th }}, 2012$. 